\title{
An Examination of Teachers' Attitudes Towards the National Park in Their Environment: The Isparta, Denizli Example
}

\author{
Aytaç Karakaş (Corresponding author) \\ Faculty of Education, Pamukkale University, Denizli, Turkey \\ E-mail: aytackarakas@gmail.com
}

\begin{abstract}
Hasan Genç
Faculty of Education, Mehmet Akif Ersoy University, Burdur, Turkey

E-mail: hagetr@yahoo.com
\end{abstract}

Received: October 31, 2020 Accepted: November 30, 2020

Published: December 14, 2020

doi:10.5296/jei.v6i2.17894 URL: https://doi.org/10.5296/jei.v6i2.17894

\begin{abstract}
Environmental education in national parks is equivalent to an open and permanent education process in which individuals and communities become aware of their natural environment and gain a critical and sensitive attitude towards it and the use of its resources. The aim of this study was to examine the attitudes of teachers towards national parks who work in schools near different national parks in terms of different variables. As a work of descriptive research, it was conducted with a total of 167 teachers who worked in schools around Kovada Lake National Park, Kızıldağ National Park, and Honaz Mountain National Park. In the study, an attitude scale with a Cronbach's Alpha coefficient of 0.83 and consisting of 32 items was used for the national parks. The SPSS (Statistical Package for Social Sciences Program) was used to evaluate the data obtained. A T-test and a one-way ANOVA test were used to analyze the data. According to the results obtained, teachers' attitudes towards the national park did not show a significant difference in terms of their gender, their tenure, the branches they serve, their purpose of visiting the national park, their opinions on the importance attached to the national park, the different schools near the national park, the national park near the schools they worked in, their purpose in visiting the national park previously while they differed significantly according to whether the teachers had visited the national park before.
\end{abstract}


Keywords: National park, National park education, Attitude

\section{Introduction}

The quality of education needs to be improved in a globalized society and should be adapted to the needs of the modern labor market, technological developments, and a multicultural society. The compliance of these changes with the competence approach in the field of education, improvements in education, reorganization of existing programs, and the concept of sustainability and lifelong education are important components that society and individuals face (Dobrila, Sladjana, \& Maja, 2018). These components focus on the basic understanding and functionality of the experience and education and training issues through the co-construction of knowledge and experience (Kelley \& Kellam, 2009; Verbitsky \& Kalashnikov, 2012). In order to improve the quality of education, it is necessary to establish a strong link between teaching material and real-life scenarios, emphasizing the importance of preparing students for life and various social roles (Anđelković \& Stanisavljević Petrović, 2013).

Nazir and Pedretti (2016, p. 295) argue that special pedagogical strategies are needed in order to raise awareness through environmental education. Students must be deeply involved in original and multidimensional outdoor activities, so that they can become ready for a transformation. Raising environmental awareness "is a complex structure that involves transforming people in multidimensional depth rather than simply promoting shallow talk or simple awareness about environmental issues" (Nazir \& Pedretti, 2016, p. 289). In this context, education should effectively use the natural heritage of protected areas and allow direct contact with nature and bring people closer to nature through aesthetic education in contact with the beauty of nature.

In environmental education, different tools are used while trying to understand the mutual relationship of people with their environment and to bring environmental awareness to society. Today, in environmental education, nature protection areas such as national parks and urban green areas, especially human and natural surroundings, are considered as a laboratory and are used for educational purposes (Atik \& Toksöz, 2005). National park education as a part of environmental education consists of nature-, history-, and culture-based scientific environmental education carried out in national parks. By introducing the natural, historical, and cultural values offered by the national parks and their immediate surroundings to the individuals through national park education, the attempt is to give people the ability to observe park qualities; to understand the natural balance; and diversity and originality in color, form, and aesthetics. As a result of national park education, individuals are expected to develop a unique style of observing and interpreting park qualities and gain responsibility. Providing an ecology-based holistic education to the participants in national parks offers the opportunity to present natural, historical, and cultural values together, thus improving the interdisciplinary thinking skills of the participants. These are among the main objectives of national park education (Ozaner, 2003).

National parks, zoos, museums, and other informal settings offer opportunities to enhance environmental learning beyond formal education. Unlike daily schooling, visits to such 
places provide new, thought-provoking experiences that arouse students' curiosity and interest, which facilitates information processing (Koran \& Longino, 1983). Studies also show that informal settings have a stronger effect on the affective sphere than structured environments (Koran, Longino, \& Shafer, 1983). Outdoor education programs can benefit intellectual development as well as the physical, affective, and spiritual development of children (Grumbine, 1988; Miles, 1986/87).

As valid areas for protecting nature in its natural state, national parks protect some of the most important natural resources of our country as well as performing education and information functions. The long-term conservation of these resources requires a comprehensive understanding of park ecosystems and the ecological processes that affect them. National parks also offer unique opportunities to learn about natural ecosystems and to serve as important bases for assessing the effects of human activities (Parsons, 1989; Graber, 2002). National parks can be viewed not only as nature preserves but also as educational resources from which lessons can be drawn about the value of natural heritage and what should be done to protect it (Morales, 1998). Environmental education regarding national parks is equivalent to an open and permanent education process in which individuals and communities become aware of their natural environment and gain a critical and sensitive attitude towards the use of their resources. This study is also important in terms of realizing the importance of national parks, increasing sensitivity towards national parks, and setting an example for similar studies.

The primary question addressed in this study is as follows: Do teachers' attitudes towards the national parks located near them differ significantly according to different variables? The sub-questions supporting the primary question are as follows:

1) Do teachers' attitudes towards the national park in the environment they live show a significant difference according to gender?

2) Is there a significant difference between the attitudes of the teachers who work near different national parks towards the national park?

3) Is there a significant difference between the attitudes of the teachers towards the national park located near them and the branches of the teachers?

4) Is there a significant difference between the attitudes of the teachers towards the national park located near them and their tenure?

5) Is there a significant difference between the attitudes of teachers towards the national park located near them and their status of visiting the national park?

6) Is there a significant difference between the attitudes of the teachers towards the national park located near them and their purpose in visiting the national park?

7) Is there a significant difference between the teachers' opinions on how much importance is attached to the national park located near them and their attitude towards the national park? 
8) Is there a significant difference between the teachers' attitudes towards the national park located near them and the schools they work in?

\subsection{Purpose of the Research}

The aim of this study was to determine the factors including their tenure, their branches, the schools they work in, whether or not they go to the national park, and the purpose of their visit that affect teachers' attitudes towards the national park, which is a part of the natural, historical, and cultural-based environmental education in the environment they live in.

\section{Methods}

\subsection{Research Model}

This research is descriptive (Karasar, 2006), and descriptive research aims to explain the interaction between situations, taking into account the relationships of current events with previous events and conditions. Independent variables are those that form the cause in a cause-effect relationship (Kaptan, 1998). In this study, the scores obtained from the Attitude Towards the National Park Scale were taken as the dependent variable. Independent variables were obtained via a personal information form.

The universe of the research consisted of 167 teachers working in 15 different schools located near Honaz Mountain National Park in Denizli and Kovada Lake and Kızıldağ National Park in Isparta. Since the population was also accepted as the sample, a separate sampling method was not used.

\subsection{Data Collection Tools of the Research}

\subsubsection{Personal Information Form}

There are independent variables about the teachers themselves in the personal information form.

\subsubsection{Attitude Towards National Park Scale}

Developed by Karakaş, Genç, Demirkaya, and Deniş (2008) in order to determine teachers' attitudes towards the National Park, the 32-item, 5-point Likert type Attitude Towards the National Park Scale with Cronbach' Alpha Coefficient $=0.83$ was used with the following ranking: Totally Agree (5), Agree (4), Neither Agree nor Disagree (3), Disagree (2), and Totally Disagree (1).

\subsection{Data Analysis}

The independent variables of this study were gender, branch, number of years they had worked in their schools, whether they had gone to the national park before, for what purpose they went to the national park, and teachers' opinions on how much importance was attached to the national park in the area where they lived.

The dependent variable of the study was teachers' attitudes towards the national park. While scoring the attitude scale, a score between 1 and 5 was given according to the chosen answer. 
A T-test and One-Way ANOVA tests were applied to determine whether there was a significant difference between the groups formed according to the responses given to the items on the attitude scale. Statistical analyses in this study were made using the SPSS package program. A 0.05 significance level was taken in the analyses. In the techniques used within the scope of the research, the results were statistically tested in two ways (Özdamar, 1999; Büyüköztürk, 2002).

\section{Findings}

3.1 Personal Findings Regarding Teachers Working at Schools Around Honaz Mountain National Park

Table 1. Descriptive statistics for different variables of teachers participating in the study

\begin{tabular}{|c|c|c|c|}
\hline Variables & Category & $\mathbf{n}$ & $\%$ \\
\hline \multirow{2}{*}{ Gender } & Female & 59 & 67.05 \\
\hline & Male & 29 & 32.95 \\
\hline \multirow{4}{*}{ Tenure } & $1-3$ years & 63 & 71.59 \\
\hline & $4-6$ years & 18 & 20.45 \\
\hline & $7-9$ years & 2 & 2.27 \\
\hline & 10 years and above & 5 & 5.68 \\
\hline \multirow{14}{*}{ Branch } & Grade & 53 & 60.22 \\
\hline & Social Studies & 5 & 5.68 \\
\hline & English & 5 & 5.68 \\
\hline & Mathematics & 4 & 4.54 \\
\hline & Pre-School & 2 & 2.27 \\
\hline & Science & 4 & 4.54 \\
\hline & Turkish & 4 & 4.54 \\
\hline & Physical Education & 2 & 2.27 \\
\hline & Technology and Design & 2 & 2.27 \\
\hline & Computer & 2 & 2.27 \\
\hline & Religious Culture and Ethics Knowledge & 1 & 1.13 \\
\hline & Visual Arts & 2 & 2.27 \\
\hline & Psychological Counseling and Guidance & 1 & 1.13 \\
\hline & Music & 1 & 1.13 \\
\hline
\end{tabular}




\begin{tabular}{|l|l|l|l|}
\hline \multirow{4}{*}{ Status of Visiting the National Park } & Visited & 66 & 76.86 \\
\cline { 2 - 4 } & Not visited & 21 & 24.14 \\
\hline \multirow{4}{*}{ Purpose of Visit } & Picnic & 48 & 71.64 \\
\cline { 2 - 5 } & Staying & 2 & 2.98 \\
\cline { 2 - 5 } & Other & 17 & 25.37 \\
\hline \multirow{4}{*}{ Status of Importance Attached } & Attached much importance & 4 & 4.54 \\
\cline { 2 - 5 } & Attached importance & 23 & 26.13 \\
\cline { 2 - 5 } & Attached Very Little Importance & 37 & 42.04 \\
\cline { 2 - 5 } & Attached No Importance & 24 & 27.27 \\
\hline
\end{tabular}

Descriptive statistics regarding different variables of the teachers working in schools around Honaz Mountain National Park are given in Table 1. When Table 1 is examined in detail, it may be seen that $59(67.5 \%)$ of the teachers were female, $63(71.59 \%)$ had tenure between 1-3 years, $53(60.22 \%)$ of them were classroom teachers, $66(76.86 \%)$ had visited the National Park before, 48 (71.64\%) had visited the National Park for a picnic, and 37 (42.04\%) attached very little importance to the national parks. 
3.2 Personal Findings Regarding Teachers Working at Schools Around Kovada Lake and Kızlldăg National Park

Table 2. Descriptive statistics for different variables of teachers participating in the study

\begin{tabular}{|c|c|c|c|}
\hline Variables & Category & n & $\%$ \\
\hline \multirow{2}{*}{ Gender } & Female & 32 & 40.51 \\
\hline & Male & 47 & 59.49 \\
\hline \multirow{4}{*}{ Tenure } & $1-3$ years & 42 & 53.16 \\
\hline & 4-6 years & 13 & 16.46 \\
\hline & $7-9$ years & 9 & 11.39 \\
\hline & 10 years and above & 15 & 18.99 \\
\hline \multirow{10}{*}{ Branch } & Grade & 43 & 54.43 \\
\hline & Social Studies & 5 & 6.33 \\
\hline & English & 6 & 7.59 \\
\hline & Mathematics & 5 & 6.33 \\
\hline & Pre-School & 2 & 2.53 \\
\hline & Science & 6 & 7.59 \\
\hline & Turkish & 4 & 5.06 \\
\hline & Physical Education & 1 & 1.27 \\
\hline & Technology Design & 5 & 6.33 \\
\hline & Computer & 2 & 2.53 \\
\hline \multirow{2}{*}{ Status of Visiting the National Park } & Visited & 75 & 96.15 \\
\hline & Not visited & 3 & 3.85 \\
\hline \multirow{4}{*}{ Purpose of Visit } & Picnic & 67 & 88.16 \\
\hline & Staying & 3 & 3.95 \\
\hline & Teaching a lesson & 2 & 2.63 \\
\hline & Other & 4 & 5.26 \\
\hline \multirow{4}{*}{ Status of Importance Attached } & Attached much importance & 42 & 53.16 \\
\hline & Attached importance & 13 & 16.46 \\
\hline & Attached very little importance & 9 & 11.39 \\
\hline & Attached no importance & 15 & 18.99 \\
\hline
\end{tabular}




\section{Macrothink}

Descriptive statistics regarding different variables of the teachers working in schools around Kovada Lake and Kızıldağ National Park are given in Table 2 where it may be seen that 47 $(59.49 \%)$ of the teachers were male, $42(53.16 \%)$ had tenure between $1-3$ years, $43(54.43 \%)$ were working as classroom teachers, 75 of $(96.15 \%)$ had visited the National Park before, 67 of them (88.16\%) had visited the National Park for a picnic, and $42(53.16 \%)$ attached much importance to the national parks.

\subsection{Findings Related to Sub-question 1}

The first sub-question of the study was expressed as "Do teachers' attitudes towards the national park in their environment show a significant difference according to gender?" Descriptive statistics for the scores of teachers' attitudes towards the national park according to their gender are presented in Table 3.

Table 3 T-test results of the scores of the attitude scale towards the national park according to gender

\begin{tabular}{|l|l|l|l|l|l|l|}
\hline Gender & N & $\mathbf{X}$ & SD & Df & $\mathbf{t}$ & $\mathbf{p}$ \\
\hline Female & 91 & 128.38 & 12.01 & 1.65 & -.868 & 0.368 \\
\hline Male & 76 & 129.93 & 10.81 & & & \\
\hline
\end{tabular}

When Table 3 is examined, it may be seen that the average of the attitude scores of the female teachers towards the national parks in their environment was 128.38 while the average of the male teachers' attitude scores was 129.93. Since the average of the attitude scores of male and female teachers are close to each other, their attitudes towards the national park are also close to each other. As can be seen in the table, the attitudes of teachers towards the national park around the schools where they work do not show a significant difference according to gender $(\mathrm{p}>.05)$.

\subsection{Findings Related to Sub-question 2}

The second sub-question of the study was, "Is there a significant difference between the attitudes of the teachers who work near different national parks towards the national park?" The one-way ANOVA test results of the attitude scores of the teachers according to the national park around the schools they work in are presented in Table 4. 
Table 4. One-way ANOVA test results of teachers' attitude scale scores by national park

\begin{tabular}{|l|l|l|l|l|l|}
\hline National Park & Sum of Squares & df & Mean Squares & F & p \\
\hline Between Groups & 639.46 & 2 & 319.73 & 2.471 & 0.88 \\
\hline Within Groups & $2,121.18$ & 164 & 129.379 & & \\
\hline Total & $21,857.65$ & 166 & & & \\
\hline
\end{tabular}

When Table 4 is examined, it may be seen that there is no significant difference in teachers' attitudes towards national parks according to the national park near the schools where they work $(p>.05)$. In other words, there is no significant relationship between the attitudes of teachers towards national parks generally and the national parks near the schools where they work.

\subsection{Findings Related to Sub-question 3}

The third sub-question of the study was expressed as "Is there a significant difference between the attitudes of the teachers towards the national park in the environment they live and their branches?" Descriptive statistics for teachers' attitude scores towards the national park according to their branches are presented in Table 5.

Table 5. One-way ANOVA test results of teachers' attitude towards national park scale scores by branch

\begin{tabular}{|l|l|l|l|l|l|}
\hline Branches & Sum of Squares & df & Mean Squares & F & p \\
\hline Between Groups & $1,957.74$ & 13 & 150.59 & 1.158 & 0.316 \\
\hline Within Group & $19,899.90$ & 153 & 130.37 & & \\
\hline Total & $21,857.65$ & 166 & & & \\
\hline
\end{tabular}

The results of the analysis show that there is no significant difference between the attitudes of teachers towards the national park in the environment in which they live and their branches $(p>.05)$. In other words, the overall attitudes of teachers did not change significantly depending on their branches.

\subsection{Findings Related to Sub-question 4}

The fourth sub-question of the study was expressed as "Is there a significant difference between the attitudes of the teachers towards the national park in the environment they live and their tenure?" Descriptive statistics for teachers' attitudes towards the national park score according to their tenure may be seen in Table 6 . 
Table 6. One-way ANOVA test results of teachers' attitudes toward national park scale scores by their tenure

\begin{tabular}{|l|l|l|l|l|l|}
\hline Tenure & Sum of Squares & df & Mean Squares & F & p \\
\hline Between Groups & 536.41 & 3 & 178.80 & 1.367 & .255 \\
\hline Within Groups & $21,321.23$ & 163 & 130.805 & & \\
\hline Total & $21,857.65$ & 166 & & & \\
\hline
\end{tabular}

When looking at the results of teachers' attitudes towards the national park scale scores according to their tenure, it may be seen that there is no significant difference between teachers' attitudes towards the national park and their tenure $(p>.05)$. In other words, the general attitudes of teachers towards the national park do not significantly differ according to their tenure.

\subsection{Findings Related to Sub-question 5}

The fifth sub-question of the study was expressed as "Is there a significant difference between the attitudes of teachers towards the national park in their environment and their status of visiting the national park?" The t-test results of teachers' scores of attitudes towards the national park according to the teachers' status of having visited the national park are presented in Table 7.

Table 7. T-test results of teachers' attitudes towards the national park scale scores according to their having visited the national park

\begin{tabular}{|l|l|l|l|l|l|l|}
\hline Status of Visiting the National Park & $\mathbf{N}$ & $\mathbf{X}$ & SD & df & t & p \\
\hline Visited & 141 & 130.17 & 11.09 & 163 & 2.878 & 0.005 \\
\hline Not visited & 24 & 123.00 & 12.38 & & & \\
\hline
\end{tabular}

When the results of the analysis performed to examine whether there is a significant difference between whether teachers had been to the national park before and their attitudes towards the national park were examined, it was seen that the attitude score average of teachers who went to the national park before was $X=130.17$, and the attitude score average of teachers who had not visited the national park was $X=123.00$. In other words, it can be said that the attitudes of teachers who had visited the national park towards the national park were more positive than the teachers who had not been to the national park. The attitudes of teachers working in schools near the national park towards the national park showed a significant difference according to their status of having visited the national park $(\mathrm{p}<.05)$. 


\subsection{Findings Related to Sub-question 6}

The sixth sub-question of the study was expressed as "Is there any significant difference between the attitudes of teachers towards the national park in the environment in which they live and their purpose in visiting the national park?" The one-way ANOVA results of teachers' scores regarding their attitude towards the national park according to their purpose in visiting the national park are presented in Table 8 .

Table 8. One-way ANOVA results of teachers' scores regarding their attitude toward the national park according to their purpose in visiting the national park

\begin{tabular}{|l|l|l|l|l|l|}
\hline Purpose in Visiting & Sum of Squares & df & Mean Squares & F & p \\
\hline Between Groups & 421.68 & 3 & 140.562 & 1.158 & .328 \\
\hline Within Groups & $16,870.52$ & 139 & 121.371 & & \\
\hline Total & $17,292.21$ & 142 & & & \\
\hline
\end{tabular}

When Table 8 is examined, the analysis results show that there was no significant difference between the attitudes of teachers towards the national park in the environment in which they live and their purpose in visiting the national park $(p>.05)$. In other words, the overall attitudes of teachers did not differ significantly depending on the purpose in visiting the national park.

\subsection{Findings Related to Sub-question 7}

The seventh sub-question of the research was expressed as "Is there a significant difference between the teachers' opinions on how much importance is attached to the national park in their area and their attitude towards the national park?" The one-way ANOVA results of teachers' attitude scores towards the national park according to whether or not importance was attached to the national park are presented in Table 9.

Table 9. ANOVA results of teachers' attitude score toward the national park according to whether or not importance was attached to them

\begin{tabular}{|l|l|l|l|l|l|}
\hline Status of Importance Attached & Sum of Squares & df & Mean Squares & F & p \\
\hline Between Groups & 239.68 & 3 & 79.896 & .602 & .614 \\
\hline Within Groups & $21,617.96$ & 163 & 132.626 & & \\
\hline Total & $21,857.65$ & 166 & & & \\
\hline
\end{tabular}


When the results of the analysis made to determine whether the attitude scores of the teachers toward the national park differed significantly according to their opinions on the importance attached to the national park were examined, it was observed that there was no significant difference between the attitudes of the teachers towards the national park located in their area and their opinions as to whether or not importance was attached to the national park $(p>.05)$.

\subsection{Findings Related to Sub-question 8}

The eighth sub-problem of the study was expressed as "Is there a significant difference between the schools where teachers work and their attitude towards the national park?" The one-way ANOVA results showing whether there was a significant difference between teachers' attitude scores towards the national park according to the schools where they work are presented in Table 10.

Table 10. ANOVA test results of teachers' attitude scale scores toward the national park according to the schools where they worked

\begin{tabular}{|l|l|l|l|l|l|}
\hline The Schools Where They Worked & Sum of Squares & df & Mean Squares & F & p \\
\hline Between Groups & $2,819.30$ & 12 & 234.942 & 1.90 & .313 \\
\hline Within Groups & $19,038.35$ & 154 & 123.626 & & \\
\hline Total & $21,857.65$ & 166 & & & \\
\hline
\end{tabular}

When the results of the analysis were examined, it was seen that there was no significant difference between the attitudes of teachers working in schools around the national park toward the national park and teachers of different schools around the national park $(p>.05)$.

\section{Discussion}

The attitudes of teachers working in different schools around national parks do not differ significantly according to gender. It was seen that the attitudes of male and female teachers towards the national park were close to each other. Yaşar and Şeremet (2008), in their study they carried out with national park visitors, concluded that gender did not have an effect on the knowledge, opinion, and consciousness of people regarding national parks education. Similarly, Deniş and Genç (2010), in their study with 8th grade students living around national parks, concluded that students' attitudes towards the national park did not differ significantly according to gender. However, Burger et al. (1999) and Dietz et al. (2002) found that females were more motivated and interested in environmental and ecological issues than males.

According to Morgan and Gramann (1989, p. 502), "three factors (frequency of exposure, duration of exposure, and initial attitudes) can affect the extent of attitude change." In this context, it was seen that there was no significant difference between teachers' attitudes towards the national park and their tenure while the attitudes of teachers working in schools 
around national parks toward the national park varied significantly according to the fact that they had been to the national park before. The attitudes of teachers who had been to the national park towards the national park were more positive than those who had not been to the national park. This result was supported by the result obtained by Tubb (2003) which showed that, when a survey was applied to the national park visitors before and after the visit, their attitudes changed in a positive way. Yaşar and Şeremet (2008) concluded that, as the frequency of individuals going to the national park increased, their gain in terms of knowledge, awareness, and responsibility for the national park increased. This shows that teachers' attitudes towards the national park do not differ according to the national park located near the schools where they work. García Fernández \& Sánchez Emeterio, (2017) achieved similar results in their study and stated that teachers' status of knowledge of wetlands in their environments did not differ. Contrary to these results, Demirkaya et al. (2020) concluded that the pre-test and post-test scores of the "Attitude Scale Towards National Parks" of prospective teachers do not differ significantly according to whether they have visited a national park before.

The results of the analysis showed that there was no significant difference between the attitudes of teachers towards the national park in the environment in which they live and their branches. Even if teachers work in schools near the national park, and these units are in their curriculum, their attitudes do not differ according to their branches. While previous research had suggested the importance of location-based education that enables students to interact directly with resources (Powers, 2004; Simmons et al., 2004), teachers appear to be more likely to participate in programs provided to them in advance.

It was seen that there was no significant difference between the attitudes of teachers towards the national park in the environment where they live and the purpose of their visiting the national park. This may be due to the teachers' relationship, which focused on recreation rather than understanding the functioning, values, and functions of protected areas despite the fact that they work in schools in the national park area.

Although there was no significant difference between the attitudes of teachers towards the national park in their environment and their opinions about whether or not importance was attached to the national park, it can be said that the reason the majority of teachers working around Kovada Lake and Kızıldağ National Park thought that much importance was attached to national parks while the majority of teachers working in schools around Honaz Mountain National Park thought that national parks had very little importance attached to them could be that these national parks are located in different provinces and that the functions and values in these regions are different. Akın (2006), in his master's thesis on Kaçkar National Park, concluded that the residents of the place where the national park was located did not adequately understand the value of protected areas and did not give the necessary importance to these areas.

It was seen that there was no significant difference between the attitudes of teachers working in schools around the national park towards the national park with the teachers of different schools around the national park. It can be said that this is due to the fact that the schools 
around the same national park had similar social and cultural values, even though teachers worked in different schools.

As Fien (1993, p. Viii) points out, “Teachers' attitudes and skills are central to determining the mix of different knowledge, skills, and sensory goals in environmental education programs and the social and political interests they serve". More efforts are required in teacher training to prepare teachers for their role in environmental education. While it is expected that individuals with adequate environmental education should be environmentally conscious, efforts to do so should focus not only on school programs but also on all public education programs in order to spread the effects of these interventions. Teachers may need to be trained on both scientific and socially critical approaches to environmental education to carry out national park education in an effective way.

\section{References}

Akın, H. M. (2006). Türkiye'deki Ekoturizmin Sürdürülebilir Gelişimi; Kaçkar Dağları Milli Parkı Örneği. Mustafa Kemal Üniversitesi, Sosyal Bilimler Enstitüsü, Hatay.

Anđelković, S., \& Stanisavljević Pešić, Z. (2013). Škola i neformalni obrazovni konteksti. Beograd: Univerzitet u Beogradu, Geografski fakultet.

Atik, M., \& Toksöz, A. (2005). Korumada Çevre Eğitimi. Korumada 50 Y1l Sempozyumu, Mimar Sinan Güzel Sanatlar Üniversitesi, İstanbul.

Burger, J., Sanchez, J., Whitfield Gibbons, J., Ondrof, J., Ramos, R., McMahon, M. J., \& Gochfeld, M. (1999). Attitudes and perceptions about ecological resources and hazards of people living Aroung the Savannah River site. Environmental Monitoring and Assessment, 57, 195-211. https://doi.org/10.1023/A:1005967608994

Büyüköztürk, Ş. (2002). Sosyal Bilimler için Veri Analizi El Kitabı. Ankara: Pegem Yayıncilik.

Demirkaya, H., Avci, D. E., Genç, H., Çeliker, H. D., Yildirim, B., Genç, D. G., ... Çal, Ü. T. (2020). An Investigation of Prospective Teachers' Attitudes towards National Parks and Views on Ecology-Based Environmental Education. Journal of Educational Issues, 6(2), 59-86. https://doi.org/10.5296/jei.v6i2.17379

Deniş, H., \& Genç, H. (2010). Investigating 8th class students' attitudes towards the national parks in their immediate environment ito the same variables (the case of Isparta province). The Journal of Graduate School of Natural and Applied Sciences of Mehmet Akif Ersoy University, 1, 9-25.

Dietz, T., Kalof, L., \& Stern, P. C. (2002). Gender, values, and environmentalism. Social Science Quarterly, 83, 353-364. https://doi.org/10.1111/1540-6237.00088

Dobrila, L., Sladjana, A., \& Maja, V. (2018). Forum geografic. Studii si Cercetări De Geografie si Protectia Mediului, XVII(2), 160-170. https://doi.org/10.5775/fg.2018.057.d

Fernández, B. G., \& Emeterio, G. S. (2017). Conceptions and perceptions of primary school 
teachers on wetlands. Wetlands, 37(6), 1045-1053. https://doi.org/10.1007/s13157-0170939-8

Fien, J. (1993). Environmental education: A pathway to sustainability. Geelong: Deakin University.

García Fernández, B., \& Sánchez Emeterio, G. (2017). Conceptions and Perceptions of Primary School Teachers on Wetlands. Wetlands, 37(6), 1045-1053. https://doi.org/10.1007/ s13157-017-0939-8

Graber, D. (2002). Scientific values of public parks (Vol. 19, No. 2, pp. 63-66). The George Wright Forum, George Wright Society.

Grumbine, E. (1988). The university of the wilderness. Journal of Environmental Education, 29(4), 3-7. https://doi.org/10.1080/00958964.1988.9942766

Kaptan, S. (1998). Bilimsel Araştırma ve İstatistik Teknikleri. Enstitüsü Dergisi, 18(2), 171-194.

Karasar, N. (1995). Bilimsel Araştırma Yöntemi: Kavramlar, Illkeler, Teknikler (p. 7). 3A Araştırma, Eğitim, Danışmanlık Ltd. Şti., Ankara.

Kelley, T., \& Kellam, N. (2009). A Theoretical Framework to Guide the ReEngineering of Technology Education. Journal of Technology Education, 20(2), 37-49. https://doi.org/ 10.21061/jte.v20i2.a.3

Koran, J., \& Longino, S. (1983). Curiosity behavior in formal and informal settings: What research says. Research Bulletin. Gainesville, FL: Florida Educational Research \& Development Council, Inc.

Koran, J., Longino, S., \& Shafer, L. (1983). A framework for conceptualizing research in natural history museums and science centers. Journal of Research in Science Teaching, 20(4), 325-339. https://doi.org/10.1002/tea.3660200407

Miles, J. (1986-87). Wilderness as a learning place. Journal of Environmental Education, 28(2), 33-40. https://doi.org/10.1080/00958964.1987.9943486

Morales, J. (1998). Guõa practica para la interpretacion del patrimonio. El arte de acercar el legado natural y cultural al publico visitante. Junta de Andalucõa, Espana.

Morgan, J. M., \& Gramann, J. H. (1989). Predicting effectiveness of wildlife education programs: A study of students' attitudes and knowledge toward snakes. Wildlife Society Bulletin (1973-2006), 17(4), 501-509.

Nazir, J., \& Pedretti, E. (2016). Educators' perceptions of bringing students to environmental consciousness through engaging outdoor experiences. Environmental Education Research, 22(2), 288-304. https://doi.org/10.1080/13504622.2014.996208

Ozaner, S. (2004). Türkiye'de Okul Dışı Çevre Eğitimi Ne Durumda, Neler Yapılmalı? Ulusal Ekoloji ve Çevre Kongresi. Abant İzzet Baysal Üniversitesi \& Biyologlar Derneği, 


\section{Macrothink}

Abant-Bolu Bildiri Kitabı (Doğa ve Çevre) (pp. 67-98).

Özdamar, K. (1999). Paket programlar ile istatistiksel veri analizi-1: SPSS-MINITAB. Kaan Kitabevi.

Parsons, D. J. (1989). Evaluating national parks as sites for long-term studies. Long-term Studies in Ecology: Approaches and Alternatives (p. 171).

Powers, A. L. (2004). An evaluation of four place-based education programs. The Journal of Environmental Education, 35(4), 17-32. https://doi.org/10.3200/JOEE.35.4.17-32

Simmons, B., Archie, M., Bedell, T., Braus, J., Holmes, G., Paden, M., ... Weiser, B. (2004). Environmental education materials: Guidelines for excellence. Washington, DC: North American Association for Environmental Education.

Tubb, K. N. (2003). An evaluation of the effectiveness of interpretation within Dartmoor National Park in reaching the goals of sustainable tourism development. Journal of Sustainable Tourism, 11(6), 476-498. https://doi.org/10.1080/09669580308667217

Verbitsky, A. A., \& Kalashnikov, V. G. (2012). Category of «Context» and contextual approach in Psychology. Psychology in Russia: State of the Art, 5(1), 117. https://doi.org/ 10.11621/pir.2012.0007

Yaşar, O., \& Şeremet, M. (2008). Türkiye'de Milli Park Eğitimi ve Milli Park Eğitimine İlişkin Bir Araştırma: Gelibolu Yarımadası Tarihi Milli Parkı. Uluslararası Sosyal Araştırmalar Dergisi, 1(5), 910-942.

\section{Copyright Disclaimer}

Copyright for this article is retained by the author(s), with first publication rights granted to the journal.

This is an open-access article distributed under the terms and conditions of the Creative Commons Attribution license (http://creativecommons.org/licenses/by/3.0/). 